\title{
Methionine and dimethylsulfoniopropionate as sources of sulfur to the microbial community of the North Pacific Subtropical Gyre
}

\author{
Daniela A. del Valle ${ }^{1, *}$, Sandra Martínez-García ${ }^{1,5}$, Sergio A. Sañudo-Wilhelmy $^{2}$, \\ Ronald P. Kiene ${ }^{3,4}$, David M. Karl ${ }^{1}$ \\ ${ }^{1}$ Department of Oceanography, Daniel K. Inouye Center for Microbial Oceanography: Research and Education (C-MORE), \\ University of Hawaii, Honolulu, Hawaii 96822, USA \\ ${ }^{2}$ Department of Biological Sciences, Marine Environmental Biology; and Department of Earth Science, \\ University of Southern California, Los Angeles, California 90089, USA \\ ${ }^{3}$ Department of Marine Sciences, University of South Alabama, Mobile, Alabama 36688, USA \\ ${ }^{4}$ Dauphin Island Sea Lab, Dauphin Island, Alabama 36528, USA \\ ${ }^{5}$ Present address: Centre for Ecology and Evolution in Microbial model Systems (EEMiS), Linnaeus University, \\ 39182 Kalmar, Sweden
}

\begin{abstract}
Methionine (Met) and dimethylsulfoniopropionate (DMSP) are 2 important substrates that can serve as sources of sulfur and carbon to microbial communities in the sea. We studied the vertical and diel distributions and the assimilation rates of dissolved Met (dMet) and dissolved DMSP (dDMSP) into proteins of different microbial groups at Stn ALOHA, in the oligotrophic North Pacific Subtropical Gyre (NPSG). Concentrations of dMet never exceeded $50 \mathrm{pM}$ and were at their daily minimum during the night-time $(<0.17 \mathrm{pM})$. dMet assimilation into proteins accounted for $<30 \%$ of the dMet lost from the dissolved pool, suggesting that other metabolic pathways were also important. Concentrations of dDMSP ranged from 0.35 to $1.0 \mathrm{nM}$ in surface waters and did not present a distinguishable diel pattern. Cell-sorted Prochlorococcus, high nucleic acid (HNA), and low nucleic acid (LNA) non-pigmented bacteria showed a clear diel pattern for dMet and dDMSP assimilation, with higher rates during the night-time. Among the different groups, HNA bacteria had the highest per-cell assimilation rate for dMet and dDMSP, but when accounting for cell numbers in each group, the HNA and LNA bacterial group assimilation rates were comparable for both dDMSP and dMet. Integrated water column (0 to $125 \mathrm{~m}) \mathrm{dDMSP}$ assimilation rates by the entire microbial assemblage were 1.7- to 5.3-fold faster than those for dMet, suggesting that dDMSP constitutes a more important source of sulfur than dMet to the microbial community of the NPSG during the time of our study.
\end{abstract}

KEY WORDS: S cycle $\cdot$ Methionine $\cdot$ DMSP $\cdot$ Amino acids $\cdot$ DOM $\cdot$ Station ALOHA $\cdot$ Oligotrophic

\section{INTRODUCTION}

In marine ecosystems, assimilation of dissolved organic matter (DOM) sustains bacterial metabolism, especially in oligotrophic regions. Sulfur (S) is an essential nutrient found in 2 of the 20 common amino acids as well as in other organic molecules (Sievert et al. 2007). S is also present in copious amounts in the ocean in the oxidized form as sulfate $(28 \mathrm{mM})$; however, many organisms prefer to obtain S from DOM in an already reduced form in order to diminish metabolic energetic expenditure (Kiene et al. 1999, 2000). The ability to reduce sulfate and assimilate it into cellular material was previously considered to be 
universal, but 2 strains of SAR11, the dominant heterotrophic bacteria in oligotrophic regions, were reported to be unable to reduce sulfate and thus require an external source of reduced $\mathrm{S}$ to grow (Tripp et al. 2008). This potential auxotrophy for reduced $S$ has now also been reported for 2 other groups: SAR86 (Dupont et al. 2012) and marine group II Euryarchaeota (Iverson et al. 2012).

The ability to assimilate organic nitrogen (N) in the form of dissolved amino acids provides a significant advantage to certain bacterial groups (e.g. Coffin 1989, Keil \& Kirchman 1991, Kujawinski 2011). Proteins, and therefore amino acids, are also an important component of the particulate matter pool (e.g. Degens 1970, Riley 1971). Methionine (Met) is an especially important amino acid because it is involved in several cellular biochemical cycles (e.g. transfer of methyl groups through the intermediate S-adenosylmethionine) and might also have an antioxidant function (Luo \& Levine 2009). Information on the abundance and dynamics of dissolved Met (dMet) in oceanic waters is scarce because of the methodological difficulties involved in detecting it at low concentrations, therefore limiting our knowledge about cycling of this amino acid in seawater. Using a specific and sensitive analytical approach for the determination of dMet, Sañudo-Wilhelmy et al. (2012) found that dMet can reach surface concentrations of up to 500 pM but may also be depleted $(<0.17 \mathrm{pM})$ in vast areas off the coast of California.

Dimethylsulfoniopropionate (DMSP) is produced by a variety of phytoplankton taxa (Keller et al. 1989). Within the cell, DMSP can act as an osmoprotectant and a cryoprotectant (Stefels et al. 1996, Welsh 2000), as a scavenger of reactive oxygen species under cellular stress conditions (Sunda et al. 2002), and as a product of overflow photosynthesis during $\mathrm{N}$ limitation (Stefels 2000). Outside the cell, DMSP can also act as a chemoattractant for bacteria, phytoplankton, and microzooplankton (Miller et al. 2004, Seymour et al. 2010). Besides these functions, DMSP constitutes an important source of both carbon (C) and $\mathrm{S}$ to the microbial community (Kiene \& Linn 2000). In the surface waters of the North Pacific Subtropical Gyre (NPSG), DMSP can satisfy up to $10 \%$ and $67 \%$ of the estimated bacterial $\mathrm{C}$ and $\mathrm{S}$ demand, respectively, due to its high turnover rates (del Valle et al. 2012). Moreover, the utilization of the DMSP-S appears to be a widespread trait among active marine bacteria (Malmstrom et al. 2004b, Vila et al. 2004).

Met and DMSP are highly interrelated compounds. Algal DMSP producers utilize Met in the synthesis of DMSP (Gage et al. 1997), and DMSP production can be controlled by Met availability (Gröne \& Kirst 1992). In turn, the DMSP produced primarily by phytoplankton can be utilized by heterotrophic bacteria to synthesize Met (Kiene et al. 1999). Moreover, both substrates can be transported from the dissolved phase into the cell interior of phytoplankton and bacteria to be utilized as a source of reduced $\mathrm{C}$ and methyl groups (Kiene \& Linn 2000, Reisch et al. 2011). In this study, we present the distribution and assimilation of dMet at Stn ALOHA in the oligotrophic NPSG and compare this source of S to dissolved DMSP (dDMSP), both for the entire microbial assemblage and by differentiating the activity of Prochlorococcus (PRO), low nucleic acid (LNA), and high nucleic acid (HNA) non-pigmented bacteria using flow cytometric cell sorting.

\section{MATERIALS AND METHODS}

\section{Study site and sampling}

Seawater samples were collected at Stn ALOHA $\left(22^{\circ} 45^{\prime} \mathrm{N}, 158^{\circ} 00^{\prime} \mathrm{W}\right)$, the sampling site for the Hawaii Ocean Time-series (HOT; Karl \& Lukas 1996), aboard the R/V 'Kilo Moana' from 22 August to 11 September 2012. All seawater samples were collected using 121 polyvinylchloride (PVC) sample bottles attached to a conductivity, temperature, and depth (CTD) rosette. Depth profiles (0 to $125 \mathrm{~m}$ ) for dMet and dDMSP concentrations and assimilation experiments were collected at 16:00 h, local time. A diel cycle experiment was conducted on 31 August and 1 September 2012, in which samples for dMet and dDMSP concentrations and assimilation experiments were collected at $25 \mathrm{~m}$ every $4 \mathrm{~h}$ for a period of $44 \mathrm{~h}$.

\section{dMet and dDMSP concentrations}

Single samples for dMet concentration analysis were filtered directly from the PVC sampling bottle using a sterile $0.8 \mu \mathrm{m} / 0.2 \mu \mathrm{m}$ AcroPak capsule filter. The filtrate (1 l) was collected in a methanol/ hydrochloric acid/Milli-Q water-washed polyethylene bottle, immediately frozen at $-20^{\circ} \mathrm{C}$, and stored until analyzed using the method of Sañudo-Wilhelmy et al. (2012). Briefly, samples were adsorbed onto a C18 resin, extracted at 2 different $\mathrm{pH}$ levels, and then quantified using liquid chromatography/tandem mass spectrometry. Triplicate samples for dDMSP concentrations were analyzed following the procedures of del Valle et al. (2012). Samples were GF/F 
filtered, and the filtrate $(3.5 \mathrm{ml})$ was preserved following the procedures detailed by Kiene \& Slezak (2006). The filtrate was then treated with sodium hydroxide to cleave DMSP into dimethylsufide, which was cryotrapped and then injected into a Shimadzu GC-14A gas chromatograph equipped with a S-selective flame photometric detector for quantification (Kiene \& Service 1991).

\section{dMet and dDMSP assimilation rates}

For determination of dMet assimilation rate constants, $13 \mathrm{ml}$ of seawater were pipetted into a series of $14 \mathrm{ml}$ serum vials. Radiolabeled L- ${ }^{35} \mathrm{~S}-\mathrm{Met}$ (specific activity: 30 to $32 \mathrm{TBq} \mathrm{mmol}^{-1}$, American Radiolabeled Chemicals) was added in a series of $1,3,5$, and $10 \mathrm{pM}$ in triplicate, and samples were incubated for $30 \mathrm{~min}$. Dead controls consisted of samples killed with trichloroacetic acid (TCA, 5\% final concentration) prior to the addition of $10 \mathrm{pM}{ }^{35} \mathrm{~S}$-Met. Preliminary tests showed that dMet assimilation behaved linearly for a period of at least $3 \mathrm{~h}$ (data not shown). At the end of the incubation, the calculated total radioactivity added to each sample was confirmed by counting a $1 \mathrm{ml}$ subsample of the spiked seawater sample in Ultima Gold scintillation cocktail. The measured total radioactivity added to the sample was always within $4 \%$ of the calculated value. The remainder of the sample was killed with cold TCA (5\% final concentration in sample), which ensures precipitation of proteins. Samples and dead controls were then filtered through a $0.2 \mu \mathrm{m}$ Nylon filter using gentle vacuum ( $<5 \mathrm{~mm} \mathrm{Hg})$, and the incubation vial was rinsed 1 time with $80 \%$ ethanol (to remove lipid-associated labeled material) and 3 times with Milli-Q water. The filter was then placed in scintillation cocktail and counted to obtain the assimilated activity. Turnover of dMet due to assimilation was calculated from the $y$ intercept of the linear regression of turnover time for each dMet addition against the added dMet concentration (Wright \& Hobbie 1966). The turnover corresponding to each dMet addition was calculated by dividing the incubation time by the fraction of total activity assimilated. This calculation assumes no assimilation at $\mathrm{T}_{0}$ of the incubation, which was corroborated by the lack of a significant assimilation (compared to blanks) in the dead controls.

Radiolabeled ${ }^{35} \mathrm{~S}-\mathrm{DMSP}$ (specific activity: 8.1 to 9.6 TBq $\mathrm{mmol}^{-1}$ ) was synthesized from ${ }^{35} \mathrm{~S}-\mathrm{Met}$ (Howard et al. 2011). Based on previous work, the addition of radiolabeled DMSP was considered to be a tracer addition (del Valle et al. 2012); therefore, only 1 amendment of ${ }^{35}$ S-DMSP $(7$ pM) was performed, in triplicate. This assumption was later confirmed when the in situ dDMSP concentrations during the time of the study were measured (0.5 to $1 \mathrm{nM}$ in situ dDMSP, see 'Results; Diel variability of dDMSP concentration and assimilation'). Samples were incubated in parallel to dMet assimilation samples. Because, in this system, the assimilation of dDMSP behaves linearly for $\sim 8 \mathrm{~h}$ (del Valle et al. 2012), only 2 time points at 1.5 and $3 \mathrm{~h}$ were taken to calculate the assimilation rate constant. The treatment of the samples was the same as for dMet rateconstant determination. The rate constant was calculated as the slope of the regression line between the fraction of the added label present in the protein fraction and time, assuming first-order kinetics and considering no significant assimilation at $\mathrm{T}_{0}$ of the incubation.

Samples for dMet and dDMSP assimilation rates from water column profiles were incubated in the dark at in situ temperature. During the diel cycle experiment, samples were incubated in a flowthrough, blue acrylic, on-deck incubator at 50\% surface irradiance levels.

\section{Cell- and group-specific dMet and dDMSP assimilation rates}

Samples for flow cytometric sorting were amended with 140 to $190 \mathrm{pM}^{35} \mathrm{~S}-$ Met or 145 to $230 \mathrm{pM}^{35} \mathrm{~S}$ DMSP and incubated in $10 \mathrm{ml}$ serum vials for $2 \mathrm{~h}$ for dMet and $2.8 \mathrm{~h}$ for dDMSP at in situ temperature under the same light/dark conditions as parallel samples for rate-constant determinations. After incubation, the samples were fixed with $0.24 \%$ vol/vol paraformaldehyde (final concentration), frozen in liquid $\mathrm{N}_{2}$, and preserved at $-80^{\circ} \mathrm{C}$ until analyzed. The abundances of PRO and heterotrophic bacteria were determined using a Cytopeia Influx Mariner flow cytometer following the procedures detailed by Martínez-García et al. (2013). For this work, cells were sorted at a rate of 100 to 200 particles $\mathrm{s}^{-1}$, and an average of $2 \times 10^{6}$ cells were sorted for each group. PRO was identified in unstained samples in plots of forward scatter (FSC) versus red fluorescence (692 nm) and then sub-gated in plots of FSC versus orange fluorescence $(580 \mathrm{~nm})$. For heterotrophic bacteria, cells were stained prior to analysis with $2.5 \mathrm{mM}$ SybrGreen I DNA fluorochrome and then classified based on plots of side scatter versus green fluorescence $(530 \mathrm{~nm})$ as HNA or LNA bacteria. These 2 subgroups could be resolved in all samples. 
Sorted cells were then filtered through a $0.2 \mu \mathrm{m}$ Nylon membrane filter (Osmonics) and rinsed with $0.2 \mu \mathrm{m}$ filtered seawater, and then the activity on the filters was counted. The activity resulting from the sorting of the HNA group was corrected for the presence of PRO. Dead controls were processed on 3 occasions following the same procedures as a live sample, but the signal obtained was not significantly higher than the blanks ( 0.17 to $0.18 \mathrm{~Bq}$ ) for any of the sorted groups for either ${ }^{35} \mathrm{~S}$-dMet or ${ }^{35} \mathrm{~S}$-dDMSP. Assimilation in dead controls was considered equal to the assimilation at the beginning of the incubation $\left(\mathrm{T}_{0}\right)$. The added concentration of labeled substrate was expected to significantly affect the in situ concentration of both dDMSP (30 to $60 \%$ ) and dMet $(>350 \%)$; however, this addition was necessary to obtain enough signal for the sorting of all groups. Because of this, dMet assimilation rates obtained using this methodological approach are higher than in situ rates and should not be considered a quantitative reflection of the actual assimilation by each group in the system but rather the relative assimilation capacity. Moreover, these rates cannot be considered 'potential' because we cannot assure that experimental concentrations were saturating. Because the assimilation of dMet by specific groups was assessed after the amendment of only 1 nontracer concentration (instead of a series of concentrations, as employed for the in situ rate constant, see above), we calculated the cell-specific assimilation rate as the product of the fraction of labeled compound assimilated per cell per unit of time and the experimental concentration, which was considered to be the sum of the in situ concentration plus the labeled amendment. Group-specific assimilation rates were calculated as the product of the cell-specific rate and the cell abundance of the corresponding group. The same calculations were performed for cell- and group-specific dDMSP assimilation rates.

\section{Effect of different $\mathrm{S}$ substrates on dMet and dDMSP assimilation}

To test for the effect of potentially competing reduced $\mathrm{S}$ substrates on the assimilation of dMet and dDMSP, samples from $25 \mathrm{~m}$ were amended with different S compounds (DMSP, methionine, cysteine, thiosulfate, and dimethylsulfoxide) at concentrations of 1,50, and $125 \mathrm{nM}$. Samples were aliquoted into $14 \mathrm{ml}$ serum vials, amended with the different $\mathrm{S}$ compounds, and incubated for $2 \mathrm{~h}$. After this pre-incuba- tion, samples were amended with either ${ }^{35} \mathrm{~S}$-DMSP $(5 \mathrm{pM})$ or ${ }^{35} \mathrm{~S}-\mathrm{Met}(5 \mathrm{pM})$, and incubated for an additional $2 \mathrm{~h}$. Samples with no S-compound added constituted the control. All treatments were carried out in quadruplicate.

\section{Statistical tests}

The significance of differences between day- and night-time assimilation rates and rate constants were tested using a $t$-test at a 0.05 level of significance. Differences among groups (PRO, LNA, and HNA) were tested for significance using 1-way analysis of variance followed by post hoc comparisons using Tukey's procedure.

\section{RESULTS}

\section{Diel variability of dMet concentration and assimilation}

In surface waters $(25 \mathrm{~m})$ of the NPSG, dMet concentrations presented a strong diel cycle, with concentrations reaching minimum values $(<0.17 \mathrm{pM})$ at night and rising to maximum values in the late afternoon (28.4 and 40.2 pM on 31 August and 1 September 2012, respectively) (Fig. 1A). Significantly higher dMet assimilation rate constants $\left(\mathrm{k}_{\mathrm{dMet}}\right)$ were observed during the night (mean $\pm \mathrm{SE}=0.083 \pm$ $\left.0.020 \mathrm{~h}^{-1}, \mathrm{n}=6\right)$ than during the day $(0.009 \pm$ $0.002 \mathrm{~h}^{-1}, \mathrm{n}=6$ ) (Fig. 1B). Because our lowest ${ }^{35} \mathrm{~S}$ dMet addition (1 $\mathrm{pM}$ ) was above the night-time dMet concentrations $(<0.17 \mathrm{pM})$, the night-time $\mathrm{k}_{\mathrm{dMet}}$ may be underestimated because increasing the pool concentration would tend to slow its turnover. If we assume that the night-time $\mathrm{k}_{\mathrm{dMet}}$ values are truly representative of the ambient conditions, then we can place an upper limit on dMet assimilation at night by multiplying the $\mathrm{k}_{\mathrm{dMet}}$ by the detection limit of the dMet concentration method $(0.17 \mathrm{pM})$. This yields estimates of dMet assimilation at night $(0.10 \pm$ $0.05 \mathrm{pM} \mathrm{h}^{-1}, \mathrm{n}=6$ ) that are significantly lower than daytime rates $\left(0.22 \pm 0.07 \mathrm{pM} \mathrm{h}^{-1}, \mathrm{n}=6\right)$ (Fig. 1C). Estimated upper limits for night-time dMet assimilation rates accounted for only 4 to $29 \%$ of the observed decrease in dMet concentrations at dusk, suggesting that there were other fates of dMet that were not measured.

dMet cell-specific and group-specific assimilation rates were significantly higher during the night compared to the day for PRO, LNA bacteria, and 


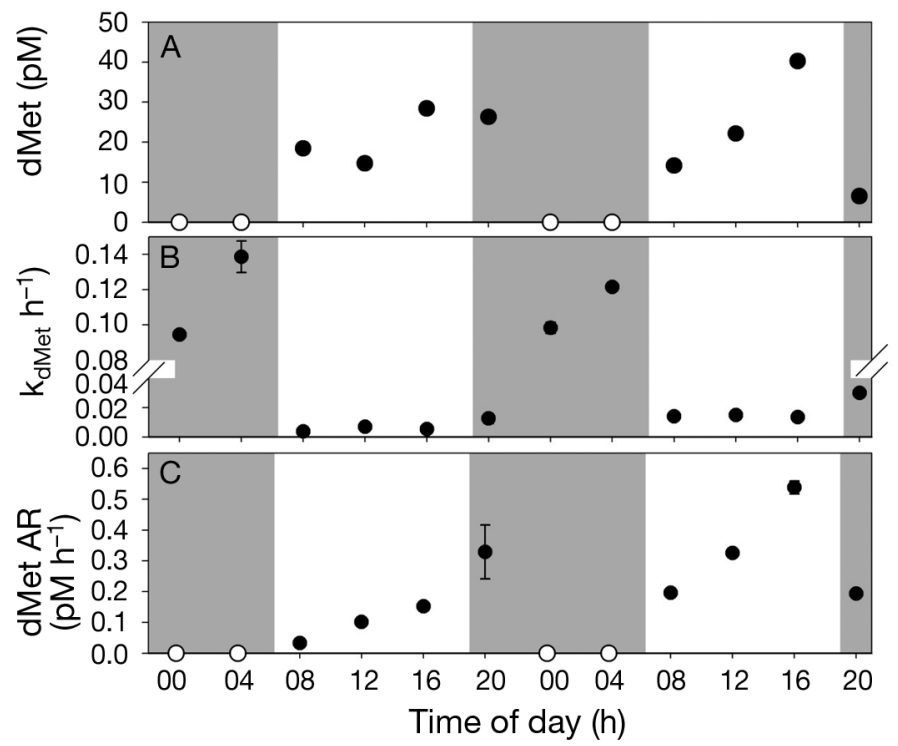

Fig. 1. Temporal variations of (A) dissolved methionine (dMet) concentrations, (B) dMet assimilation rate constants $\left(\mathrm{k}_{\mathrm{dMet}}\right)$, and (C) dMet assimilation rates (AR). Open circles denote times of the day at which dMet was below the detection limit $(0.17 \mathrm{pM})$. Seawater from $25 \mathrm{~m}$ was sampled every $4 \mathrm{~h}$ on 31 August and 1 September 2012, at Stn ALOHA. Grey background indicates night-time, while white background indicates daytime. Error bars in (B) and (C) denote standard deviation and are shown when larger than symbols
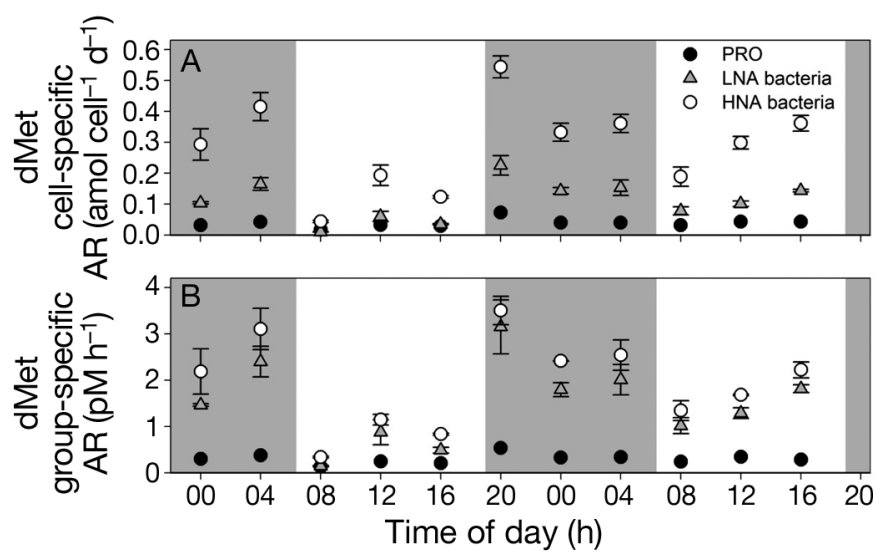

Fig. 2. Temporal variations of (A) cell-specific and (B) groupspecific dMet assimilation rates (AR). Rates were obtained after addition of non-tracer ${ }^{35} \mathrm{~S}$-dMet concentrations and therefore are not a reflection of in situ rates. Seawater from $25 \mathrm{~m}$ was sampled every $4 \mathrm{~h}$ on 31 August and 1 September 2012 at Stn ALOHA. PRO: Prochlorococcus, LNA bacteria: low nucleic acid bacteria, HNA bacteria: high nucleic acid bacteria. Grey background indicates night-time, while white background indicates daytime. Error bars denote standard deviation and are shown when larger than symbols

HNA bacteria (Fig. 2). HNA bacteria presented higher cell-specific dMet assimilation rates than LNA during both the day- and night-time (Fig. 2A). However, dMet group-specific assimilation rates were not significantly different between these 2 groups during either the day- or nighttime (Fig. 2B). Cell-specific dMet assimilation rates by PRO were significantly lower than by HNA bacteria during the day- and night-time but were only significantly lower than LNA bacterial assimilation rates during the night-time (Fig. 2A). However, dMet group-specific assimilation rates by PRO were significantly lower than by HNA and LNA bacteria for both day- and night-time (Fig. 2B).

\section{Diel variability of dDMSP concentration and assimilation}

Daytime concentrations of dDMSP $(0.42 \pm 0.02 \mathrm{nM}$, $\mathrm{n}=6$ ) were not significantly different from nighttime concentrations $(0.42 \pm 0.03 \mathrm{nM}, \mathrm{n}=6)$ ) (Fig. $3 \mathrm{~A})$. dDMSP assimilation rate constants $\left(\mathrm{k}_{\mathrm{dDMSP}}\right)$ and dDMSP assimilation rates were significantly higher during the night than during the day $(4.9 \times$ $10^{-3} \pm 0.4 \times 10^{-3} \mathrm{~h}^{-1}$ vs. $3.2 \times 10^{-3} \pm 0.3 \times 10^{-3} \mathrm{~h}^{-1}$ and $2.04 \pm 0.15 \mathrm{pM} \mathrm{h}^{-1}$ vs. $1.35 \pm 0.18 \mathrm{pM} \mathrm{h}^{-1}$ ) (Fig. 3B,C).

Cell-specific and group-specific dDMSP assimilation rates were significantly higher during the night than during the day for all groups studied (i.e. PRO, LNA, and HNA) (Fig. 4). During the night, HNA bacteria presented the highest cellspecific dDMSP assimilation rate compared to both PRO and LNA bacteria. During the day, the cell-

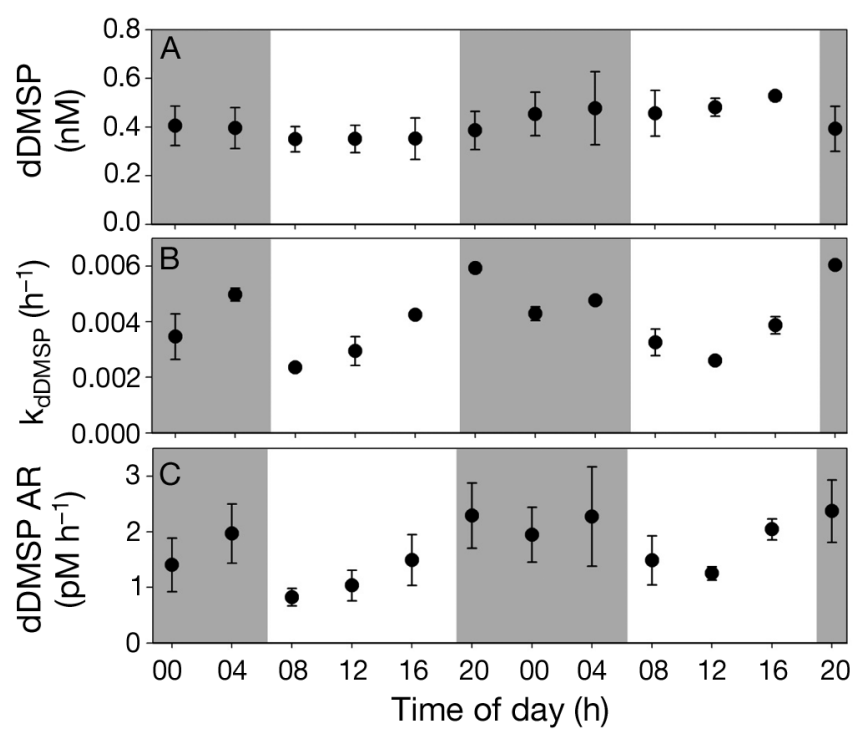

Fig. 3. Temporal variations of (A) dissolved dimethylsulfoniopropionate (dDMSP) concentrations, (B) dDMSP assimilation rate constants $\left(\mathrm{k}_{\mathrm{dDMSP}}\right)$, and $(\mathrm{C}) \mathrm{dDMSP}$ assimilation rates (AR). See Fig. 2 for further details 

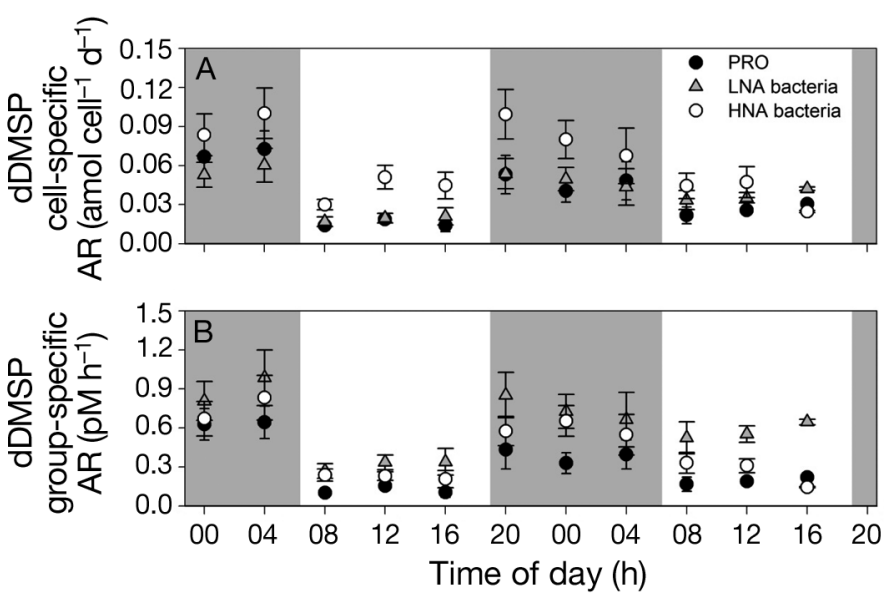

Fig. 4. Temporal variations of (A) cell-specific and (B) groupspecific dDMSP assimilation rates (AR). See Fig. 2 for further details

specific dDMSP assimilation rate of HNA was significantly higher than that of PRO but not of LNA (Fig. 4A). During the night and day, dDMSP cellspecific assimilation rates were not significantly different between PRO and LNA bacteria (Fig. 4A). When accounting for cell abundances of each group, dDMSP group-specific assimilation rates by LNA bacteria were significantly higher than by PRO (night- and daytime) and HNA bacteria (daytime only) (Fig. 4B). No significant difference was observed in group-specific dDMSP assimilation rates between PRO and HNA bacteria during either the day or the night (Fig. 4B).

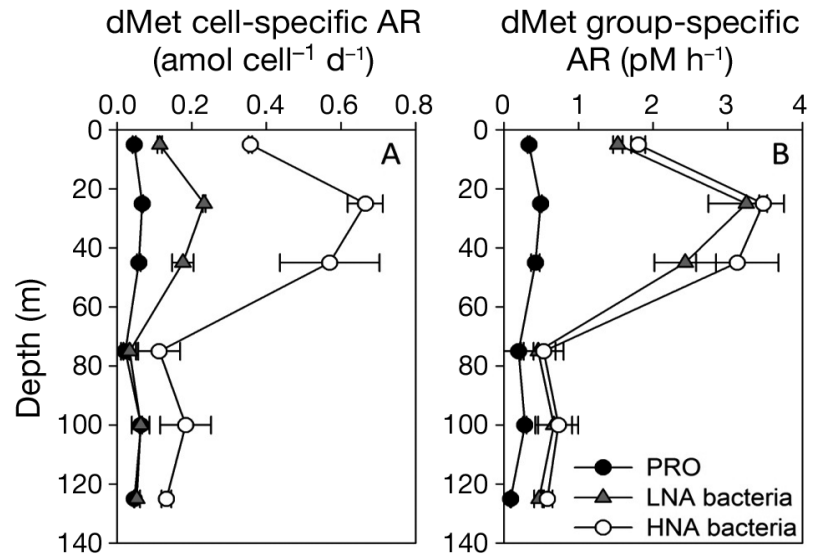

Fig. 6. Vertical profiles (5 to $125 \mathrm{~m}$ ) of (A) cell-specific and (B) group-specific dMet assimilation rates (AR), carried out at Stn ALOHA. Rates were obtained after addition of nontracer ${ }^{35} \mathrm{~S}$-dMet concentrations and therefore are not a reflection of in situ rates. The data in each graph correspond to the average of the profiles obtained on 3 and 7 September 2012. Error bars denote absolute error. PRO: Prochlorococcus, LNA bacteria: low nucleic acid bacteria, HNA bacteria: high nucleic acid bacteria

\section{Depth variability of dMet concentration and assimilation}

dMet concentrations presented a maximum near the surface $(5 \mathrm{~m})$, and overall, they were higher ( 8.7 to $49.2 \mathrm{pM}$ ) in the surface mixed layer (SML: 0-47 $\mathrm{m}$ and 0-38 $\mathrm{m}$ on 3 and 7 September 2012, respectively) compared to deeper depths (2.7 to $12.5 \mathrm{pM}$, >SML to $125 \mathrm{~m}$ ) (Fig. 5A). Profiles were conducted at 16:00 h, the time when maximum diel dMet concentrations were observed at $25 \mathrm{~m}$ (Fig. 1); therefore, concentrations represent an upper limit to the dMet pool. SML-integrated dMet concentrations were 1.65 and $0.48 \mu \mathrm{mol} \mathrm{m}{ }^{-2}$ on 3 and 7 September, respectively, with a larger dMet pool on 3 September due to higher dMet concentrations and deeper SML. The $\mathrm{k}_{\mathrm{dMet}}$ assimilation values were also higher in the SML compared to deeper depths, and within the SML, they ranged from 0.03 to $0.10 \mathrm{~h}^{-1}$ (Fig. 5B). Higher dMet and $\mathrm{k}_{\mathrm{dMet}}$ in the SML yielded higher dMet assimilation rates at these depths (Fig. 5C).

Throughout the water column (5 to $125 \mathrm{~m})$, HNA bacteria had the highest cell-specific dMet assimilation rate, but the HNA group-specific assimilation rate was comparable to LNA bacteria (Fig. 6A,B). PRO presented the
Fig. 5. Vertical profiles (5 to $125 \mathrm{~m}$ ) of (A) dMet concentrations, (B) dMet assimilation rate constants $\left(\mathrm{k}_{\mathrm{dMet}}\right)$, and $(\mathrm{C})$ dMet assimilation rates (AR) carried out at Stn ALOHA on 3 and 7 September 2012. Profiles were sampled at 16:00 $\mathrm{h}$, time of the maximum dMet concentration measured (see Fig. 1). Dashed and dotted lines represent the depth of the SML on 3 and 7 September, respectively. Error bars in (B) and (C) denote standard deviation and are shown when larger than symbols 


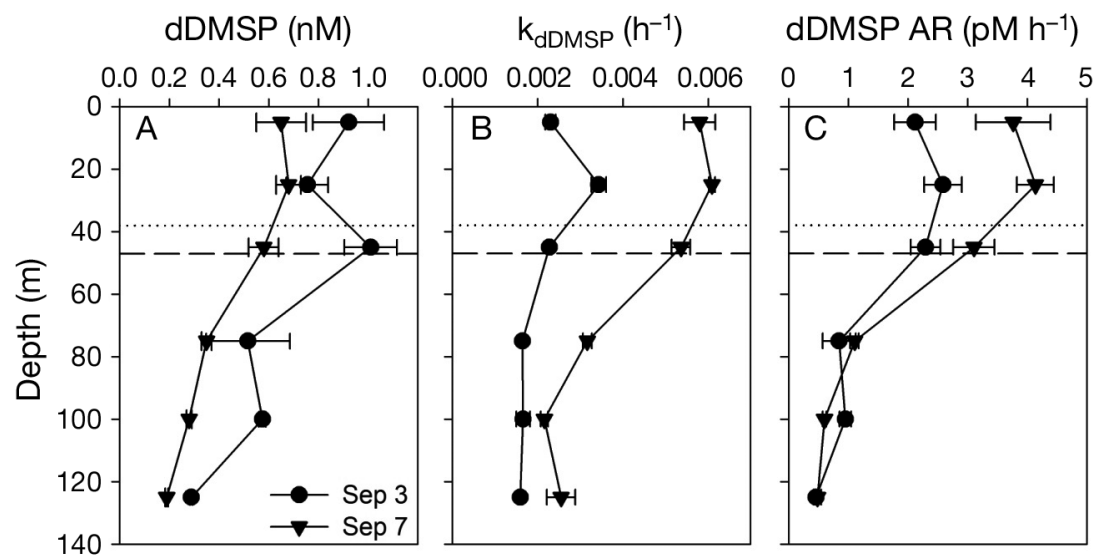

Fig. 7. Vertical profiles (5 to $125 \mathrm{~m}$ ) of (A) dDMSP concentrations, (B) dDMSP assimilation rate constants $\left(\mathrm{k}_{\mathrm{dDMSP}}\right)$, and $(\mathrm{C}) \mathrm{dDMSP}$ assimilation rates (AR), carried out at Stn ALOHA on 3 and 7 September 2012. See Fig. 5 for further details

lowest dMet cell-specific assimilation rate from 5 to $45 \mathrm{~m}$, but the PRO rate was comparable to the LNA bacterial per cell assimilation rate below $75 \mathrm{~m}$ (Fig. 6A). PRO had the lowest group-specific dMet assimilation rate throughout the water column, while LNA and HNA bacteria presented comparable rates (Fig. 6B).

\section{Depth variability of dDMSP concentration and assimilation}

dDMSP concentrations were higher within the SML (0.58 to $1.01 \mathrm{nM})$ and decreased with depth (0.19 to $0.57 \mathrm{nM}$, >SML to $125 \mathrm{~m}$ ) (Fig. 7A). Within the top $125 \mathrm{~m}$ of the water column, dDMSP and dMet concentrations were correlated (Pearson's coefficient $\mathrm{r}=0.63, \mathrm{p}=0.03, \mathrm{n}=10$ ). SML-integrated dDMSP concentrations were 40.5 and $24.7 \mu \mathrm{mol} \mathrm{m}^{-2}$ on 3 and 7 September, respectively. $\mathrm{k}_{\mathrm{dDMSP}}$ ranged from $2.3 \times$ $10^{-3}$ to $6.1 \times 10^{-3} \mathrm{~h}^{-1}$ and were also higher in the SML than at greater depths (Fig. 7B). Higher dDMSP and $\mathrm{k}_{\mathrm{dDMSP}}$ in the SML yielded higher dDMSP assimilation rates at these depths compared with deeper depths (Fig. 7C).

Within the top $125 \mathrm{~m}$ of the water column, LNA bacteria and PRO presented comparable cell-specific dDMSP assimilation rates, while cell-specific dDMSP sulfur assimilation by HNA bacteria was significantly higher in the 25 to $100 \mathrm{~m}$ depth range (Fig. 8A). In contrast, within the SML, group-specific dDMSP assimilation rates by LNA bacteria were higher than by PRO and HNA bacteria, but this difference diminished with depth (Fig. 8B).

\section{Contribution of cell-sorted groups to dMet and dDMSP assimilation}

Combining all samples measured, PRO, LNA, and HNA bacterial relative abundance was, on average ( $\pm 1 \mathrm{SE})$, $26.4 \pm 0.8 \%, 50.3 \pm 0.8 \%$, and $23.3 \pm$ $0.7 \%$, respectively, of the total bacterial assemblage (Fig. 9). PRO assimilated only $11.1 \pm 1.8 \%$ of the total dMet (Fig. 9A), a much lower percentage than expected based on abundance, but was responsible for $24.2 \pm$ $1.4 \%$ of the assimilated dDMSP (Fig. 9D). LNA bacteria were responsible for the assimilation of $39.1 \pm 1.2 \%$ and $46.1 \pm 1.8 \%$ of the total dMet and dDMSP, respectively (Fig. 9B,E). HNA bacteria were responsible for $49.8 \pm 0.5 \%$ and $29.7 \pm$ $1.4 \%$ of the total assimilation of dMet and dDMSP, respectively (Fig. 9C,F).

\section{Effect of S-containing compounds on dMet and dMet assimilation}

Assimilation of dMet was significantly suppressed by nM additions of cysteine (Cys), DMSP, and thiosulfate, with the strongest suppression of dMet assimilation caused by Cys (Table 1). No significant effect of dimethylsulfoxide was observed. Added concentrations of S-containing substrates $(1,25$, and $125 \mathrm{nM})$ were 26-, 650-, and 3300-fold greater than the in situ dMet concentration $(38.5 \mathrm{pM})$, respectively.

\section{dDMSP cell-specific AR dDMSP group-specific (amol cell-1 $\mathrm{d}^{-1}$ ) AR $\left(\mathrm{pM} \mathrm{h}^{-1}\right)$}

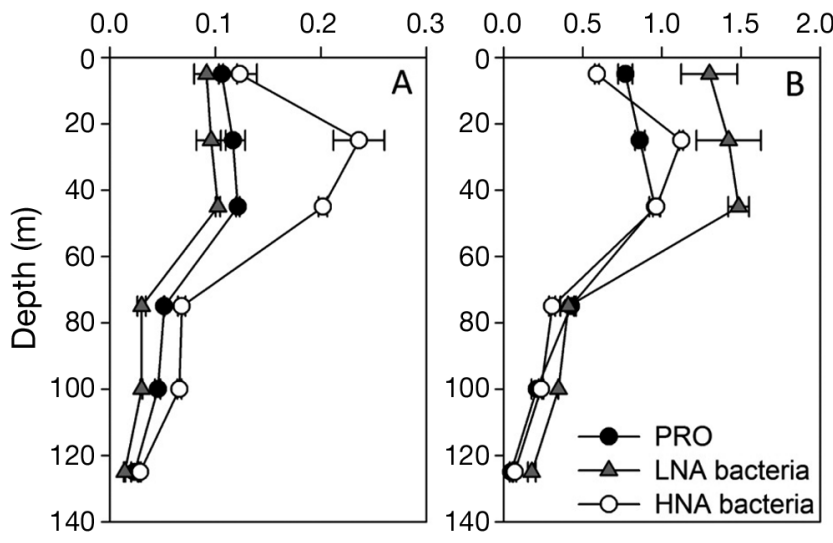

Fig. 8. Vertical profiles (5 to $125 \mathrm{~m}$ ) of (A) cell-specific and (B) group-specific dDMSP assimilation rates (AR), carried out at Stn ALOHA. See Fig. 6 for further details 

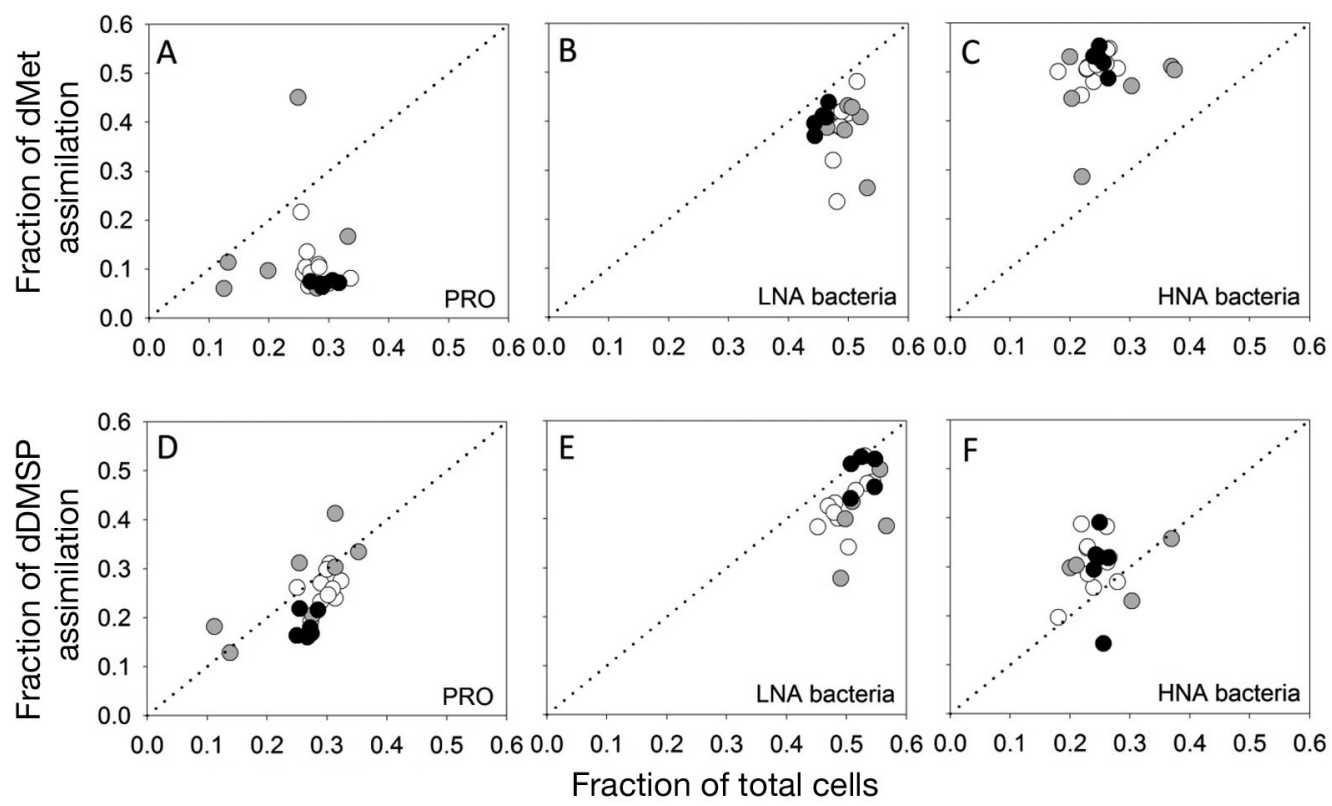

Fig. 9. Contribution of (A,D) Prochlorococcus (PRO), (B,E) low nucleic acid (LNA), and (C,F) high nucleic acid (HNA) bacteria to total $(\mathrm{A}-\mathrm{C}){ }^{35} \mathrm{~S}$ methionine and $(\mathrm{D}-\mathrm{F}){ }^{35} \mathrm{~S}-$ DMSP assimilation. White circles correspond to daytime measurements within the surface mixed layer (SML), grey circles correspond to daytime measurements below the SML, and black circles correspond to night-time measurements within the SML. The dotted line represents the 1:1 line, as a reference

The addition of nM concentrations of dMet, Cys, and dimethylsulfoxide significantly suppressed dDMSP assimilation, with the strongest suppression of dDMSP assimilation caused by dMet. No significant effect of thiosulfate was observed. Added concentrations of S-containing substrates $(1,25$, and $125 \mathrm{nM}$ ) were 1.4-, 35-, and 170-fold greater than the in situ dDMSP concentration $(0.71 \mathrm{nM})$, respectively.

\section{DISCUSSION}

\section{dMet and dDMSP concentrations}

In surface waters of the NPSG, dMet concentrations exhibited a strong diel cycle, with minimum concentrations $(<0.17 \mathrm{pM})$ at night and maximum concentrations (28.4 to $40.2 \mathrm{pM}$ ) in the late afternoon (Fig. 1A). Carlucci et al. (1984) also reported diel patterns of the total pool of free dissolved amino acid, as well as some specific amino acids, in the coastal waters of southern CA but did not specifically report patterns for dMet. These temporal variations represent an imbalance between production and consumption of dMet, with net production in the early morning and net consumption in the late afternoon. In contrast to dMet, dDMSP concentrations were uniform throughout the diel cycle, varying between 0.35 and $0.52 \mathrm{nM}$ (Fig. 3A). Even though methodological shortcomings, including but not limited to filtration artifacts (Kiene \& Slezak 2006), might have masked minor variations in dDMSP concentrations, it appears that dDMSP is available in the upper water column at all times, in contrast to dMet.

Depth profiles of dMet and dDMSP were similar (Figs. 5A \& 7A), with highest concentrations in the SML that decreased to $<30 \%$ of the surface value by

Table 1. Percentage suppression of dissolved dimethylsulfoniopropionate (dDMSP) and dissolved methionine (dMet) assimilation by the addition of 1,25 , or $125 \mathrm{nM}$ of a competitive sulfur (S) containing substrate. Percentages (SD) are provided when there was a significant statistical difference between assimilation in the treatment (substrate added) and the control (no substrate added) $(t$-test, $\mathrm{p}<0.05)$. NS: not significant. \% Suppression $=[1-($ assimilation treatment $/$ assimilation control)] $\times 100 \%$

\begin{tabular}{|c|c|c|c|}
\hline $\begin{array}{l}\text { S amendment } \mathrm{A} \\
\text { co }\end{array}$ & $\begin{array}{c}\text { Amendment } \\
\text { concentration } \\
\text { (nM) }\end{array}$ & $\begin{array}{r}\text { \% Suppre } \\
\text { Assimilation } \\
{ }^{35} \text { S-dDMSP }\end{array}$ & $\begin{array}{l}\text { ssion } \\
\text { substrate: } \\
{ }^{35} \text { S-dMet }\end{array}$ \\
\hline DMSP & $\begin{array}{r}1 \\
25 \\
125\end{array}$ & & $\begin{array}{c}\text { NS } \\
16(1) \\
24(2)\end{array}$ \\
\hline Methionine & $\begin{array}{r}1 \\
25 \\
125\end{array}$ & $\begin{array}{l}67(3) \\
81(8) \\
85(4)\end{array}$ & \\
\hline Cysteine & $\begin{array}{r}1 \\
25 \\
125\end{array}$ & $\begin{array}{l}38(7) \\
47(5) \\
44(5)\end{array}$ & $\begin{array}{r}8(3) \\
37(2) \\
42(4)\end{array}$ \\
\hline Thiosulfate & $\begin{array}{r}1 \\
25 \\
125\end{array}$ & $\begin{array}{l}\text { NS } \\
\text { NS } \\
\text { NS }\end{array}$ & $\begin{array}{c}\text { NS } \\
16(2) \\
18(3)\end{array}$ \\
\hline Dimethylsulfoxide & $\begin{array}{r}\text { de } \\
25 \\
125\end{array}$ & $\begin{array}{l}31(4) \\
36(10) \\
40(3)\end{array}$ & $\begin{array}{l}\text { NS } \\
\text { NS } \\
\text { NS }\end{array}$ \\
\hline
\end{tabular}


Table 2. Dissolved methionine (dMet) concentrations and turnover times due to assimilation reported in the literature with information on the analytical technique used to collect them. NA: not available. All turnover times were obtained using a radioisotope dilution approach

\begin{tabular}{|c|c|c|c|c|c|}
\hline Location & $\begin{array}{l}\text { Depth } \\
\text { (m) }\end{array}$ & Conc. (nM) & dMet & $\begin{array}{l}\text { Turnover } \\
\text { (d) }\end{array}$ & Source \\
\hline South Atlantic Gyre & $\begin{array}{c}3-80 \\
120-150\end{array}$ & $\begin{array}{l}0.40 \pm 0.13^{\mathrm{b}} \\
0.54 \pm 0.10^{\mathrm{b}}\end{array}$ & Radioisotope dilution & $\begin{array}{l}1.30 \pm 0.44^{\mathrm{b}} \\
2.50 \pm 0.75^{\mathrm{b}}\end{array}$ & Zubkov et al. (2004) \\
\hline South Atlantic Gyre & $5-7$ & $0.37 \pm 0.13^{\mathrm{b}}$ & Radioisotope dilution & $1.61 \pm 0.64^{\mathrm{b}}$ & Zubkov \& Tarran (2005) \\
\hline South Subtropical Frontal Zone & $5-7$ & $0.28 \pm 0.16^{\mathrm{b}}$ & & $0.41 \pm 0.22^{\mathrm{b}}$ & \\
\hline Atlantic Ocean ${ }^{\mathrm{a}}$ & $2-7$ & $\sim 0.1$ to 1.2 & Radioisotope dilution & 0.25 to 2.33 & Mary et al. (2008) \\
\hline North and South Atlantic Gyres & $3-7$ & $0.73 \pm 0.27^{b}$ & Radioisotope dilution & $\sim 0.05$ to 37 & Hill et al. (2011) \\
\hline Coastal California & $0-800$ & $<0.00017$ to 0.5 & $\mathrm{C}-\mathrm{LC} / \mathrm{MS} / \mathrm{MS}^{\mathrm{c}}$ & NA & $\begin{array}{l}\text { Sañudo-Wilhelmy et al. } \\
\text { (2012) }\end{array}$ \\
\hline NPSG & $5-125$ & $<0.00017$ to 0.05 & $\mathrm{C}-\mathrm{LC} / \mathrm{MS} / \mathrm{MS}^{\mathrm{c}}$ & 0.3 to 11.1 & This study \\
\hline
\end{tabular}

$125 \mathrm{~m}$. A similar depth distribution for dDMSP has been previously observed at Stn ALOHA (del Valle et al. 2012). In contrast, there does not appear to be a consistent depth distribution of dMet based on previous studies in other areas. Zubkov et al. (2004) reported variable dMet concentrations in the 3 to $150 \mathrm{~m}$ depth range in the Southern Atlantic tropical gyre. In a transect study carried out along the California and Baja California margin, Sañudo-Wilhelmy et al. (2012) observed regional variability, with distinct areas in which dMet concentrations were either lower in the upper $150 \mathrm{~m}$ compared to deeper waters, higher in the top $150 \mathrm{~m}$, or uniformly low (below detection limit of $0.17 \mathrm{pM}$ ) over the full depth profile. These different patterns were attributed to the presence of different water masses between 100 and $800 \mathrm{~m}$. Our depth profiles were carried out in the afternoon, therefore facilitating the observation of depth gradients because the upper water column, which is most likely to be affected by diel variability, presented maximum concentrations at this time of the day (Fig. 1A). If our dMet profiles would have been carried out exclusively during the night, we probably would have reported concentrations below the detection limit throughout the water column and, hence, no depth pattern.

Previous estimates of dMet concentrations ( 0.1 to $1.2 \mathrm{nM}$ ), obtained using the radioisotope dilution technique, are significantly higher than those observed in our study (Table 2). The reason behind the difference in dMet concentrations observed may be geographical or methodological. The use of the radioisotope dilution technique may result in over- estimations of the concentration of a substrate if the concentrations added are much higher than the in situ concentration. This overestimation is caused by the activation of alternative or complementary transport systems at higher concentrations that would otherwise be inactive under in situ conditions (Azam \& Hodson 1981, Fuhrman \& Ferguson 1986). Moreover, estimates obtained using this approach must be considered a maximum estimate, even when amendments are kept at very low concentrations (Wright \& Hobbie 1966).

The highest SML dDMSP concentration observed in this study was $1.0 \mathrm{nM}$ (Fig. 7A), which is 20 -fold greater than the highest observed concentration of dMet. The SML-integrated dDMSP pool was 30.4and 63.7-fold higher than the integrated dMet pool on 3 and 7 September, respectively, considering the dMet concentration at its diel maximum. Therefore, dDMSP is a more readily available substrate than dMet, not only due to its constant presence throughout the day but also because of its greater abundance.

\section{Whole-community dMet and dDMSP assimilation}

dMet turnover times due to assimilation in the NPSG $(1.04 \pm 0.49 \mathrm{~d}$ and $2.97 \pm 0.82 \mathrm{~d}$ during day- and night-time, respectively) are comparable to observed turnover times in the Atlantic Ocean gyres (Table 2). Small differences in turnover times might be due to a differential metabolic utilization of dMet at different locations. Diverse biogeochemical characteristics of 
the different locations might cause dMet to be channeled into different metabolic uses that may compete with direct assimilation into proteins. At Stn ALOHA, the rapid decrease in dMet concentrations at night cannot be accounted for exclusively by assimilation into cells $(<29 \%)$, meaning that, at least at this time of the day, dMet is not only being assimilated into proteins but is also metabolized in some other way. Respiration constitutes a major sink for certain amino acids, although the fraction that is respired is dependent on the specific amino acid (Suttle et al. 1991) and its concentration (J.R. Casey, P.J. Falkowski \& D.M. Karl pers. comm.). For example, respiration has been reported to account for 60 to $80 \%$ of the losses of added glutamate, glutamine, glycine, and alanine but only 5 to $10 \%$ of leucine losses (Suttle et al. 1991, Hill et al. 2013). The lower respiration of leucine might be because this amino acid is primarily directed into protein synthesis instead of being routed to respiration pathways (Kirchman et al. 1985). Regardless of the ultimate metabolic fate of dMet, this substrate must be of importance to the microbial community, since driving the dMet concentrations as low as observed during the night probably requires costly, highly efficient uptake systems.

Throughout the day, dMet accumulates, which, at least partly, is due to an increase in dMet turnover time due to assimilation (Fig. 1). This increase in concentration might also be partly caused by a decrease in the importance of other sinks of dMet (e.g. respiration, as discussed above, or production of DMSP; Stefels 2007) and/or a higher release of Met into the dissolved phase during daytime than at night. Although we could not find specific information about Met, amino acid synthesis by phytoplankton has been observed to be linked to primary production (Hammer \& Brockmann 1983), which in turn may be accompanied by a greater release or leakage into the dissolved phase during daytime (Carlucci et al. 1984). Autolysis of cells, viral lysis, and grazing might be other factors contributing to the increase of dMet concentrations during the day.

Assimilation rates of dDMSP presented a clear diel cycle, with higher assimilation during the night; however, dDMSP concentrations lacked any clear diel pattern (Fig. 3). Since assimilation of dDMSP into proteins is known to be only a minor fate of DMSP metabolism in oligotrophic waters, constituting only $2 \%$ of the metabolized dDMSP (del Valle et al. 2012), it is expected that changes in dDMSP assimilation rates will not translate into obvious changes in dDMSP concentrations. However, turnover times due to dDMSP consumption (i.e. sum of assimilation, oxi- dation, and transformation into volatiles) are rapid within the SML, ranging from 4.1 to $7.4 \mathrm{~h}$, which indicates that this is a very dynamic pool (del Valle et al. 2012). The fact that most of the dDMSP is not assimilated could suggest that it is not important as a $\mathrm{S}$ source; however, because of the size of the pool, the small fraction of dDMSP assimilated contributed 20 to $67 \%$ of the bacterial S demand in these oligotrophic waters (del Valle et al. 2012).

Compared to SML-integrated dMet assimilation rates, dDMSP assimilation rates were 1.7- and 5.3fold faster (on 3 and 7 September 2012, respectively), indicating that dDMSP constitutes a more important source of $\mathrm{S}$ than dMet for the microbial community as a whole under natural conditions during the time of our study. This pattern is driven by the higher abundance of the dDMSP pool, since microbes appear to prefer dMet against dDMSP, if dMet were to be present at comparable concentrations (Table 1). dDMSP assimilation was greatly suppressed by $\mathrm{nM}$ additions of dMet, while additions of dDMSP had a lesser effect on dMet assimilation (Table 1), which highlights the importance of dMet acquisition for microbes in this system. Cys significantly suppressed the assimilation of dDMSP and to a lesser extent of dMet (Table 1). Cys is an essential amino acid that can be synthesized from Met and also from DMSP (Kiene et al. 1999). The effect of Cys additions to dDMSP and dMet assimilation emphasizes how interrelated these compounds are in sulfur amino acid metabolism. The effect of Cys on dDMSP and dMet assimilation suggests that these compounds are precursors of Cys in this system and/or that Cys can act as a precursor of Met and DMSP and therefore replace the need for their uptake if Cys is available at sufficiently high concentrations.

\section{Group-specific dMet and dDMSP assimilation}

PRO is a group of phototrophic cyanobacteria that is abundant in the surface waters of the central oligotrophic areas of the ocean, with average cell concentrations of $1.7 \times 10^{5}$ cell ml $^{-1}$ at $25 \mathrm{~m}$ at Stn ALOHA (2007 to 2011, http://hahana.soest.hawaii.edu/hot/ hot-dogs/). One possible adaptive advantage over other taxa that allows PRO to succeed in highly oligotrophic environments is its capacity to incorporate organic substrates (Rocap et al. 2003, Zubkov et al. 2003). Even though PRO has all of the genes necessary to synthesize amino acids (Rocap et al. 2003), it has been reported to be an important contributor to amino acid cycling. In culture, PRO assimilates Met 
and leucine at high rates despite the presence of a much higher concentration of ammonium in the media (Mary et al. 2008), suggesting that there is a preference for amino acids, presumably because they can be directly incorporated into proteins. At Stn ALOHA, PRO accounted for, on average, only $11.1 \%$ of total dMet assimilation in the SML, a much lower percentage than what would be expected based exclusively on its abundance (27\%) (Fig. 9). In the Arabian Sea and the South Atlantic Ocean, the percentage of dMet assimilated by PRO was similar to what was expected based on its abundance (Zubkov et al. 2003, Zubkov \& Tarran 2005). However, at Stn ALOHA, PRO does not appear to exert a strong competitive pressure on other microbial populations with respect to dMet assimilation. The reasons behind this low assimilation of dMet by PRO are not clear. One possibility might be that the transport of organic compounds naturally present at such low concentrations (low pM), and even virtually absent at certain times of the day, is not energetically favorable for PRO. Also, PRO may not be able to regulate the uptake of dMet as efficiently as LNA and HNA bacteria (Rocap et al. 2003, García-Fernández et al. 2004) in response to the enriched concentrations of dMet utilized for our flow sorting experiments (140 to $190 \mathrm{pM})$. This would represent a significant disadvantage to PRO if it cannot respond quickly to increased fluxes of essential organic nutrients. Michelou et al. (2007) reported that PRO contributed up to $24 \%$ of total leucine assimilation when supplied at a concentration of $20 \mathrm{nM}$ but only $10 \%$ of the assimilation of a mix of different amino acids supplied at $0.5 \mathrm{nM}$, which could suggest that PRO might compete better for amino acid uptake when these are present at high concentrations. However, these results may also be explained by a preferential assimilation of leucine, as explained in 'Whole-community dMET and dDSMP assimilation'. At Stn ALOHA, assimilation by PRO of leucine supplied in the pM range ( 160 pM) was also much lower than expected based on abundance (13\%, data not shown), similar to dMet assimilation. In contrast, PRO were more competitive in the assimilation of dDMSP, being responsible for 26 and $18 \%$ of total assimilation during the day and night, respectively, suggesting that PRO have a preference for DMSP as their $\mathrm{S}$ source.

Bacterial cells with HNA and LNA content have been extensively discriminated using flow cytometry (e.g. Li et al. 1995, Gasol et al. 1999, Lebaron et al. 2001, Zubkov et al. 2001, Mary et al. 2006). Several studies have reported the presence of SAR11 exclu- sively within the LNA bacterial group (Mary et al. 2006, Hill 2010, Schattenhofer et al. 2011, Vila-Costa et al. 2012), although to our knowledge this has not been investigated in the Pacific Ocean. Based on SAR11 typical abundance at Stn ALOHA (Eiler et al. 2009) and their incapacity to reduce sulfate (Tripp et al. 2008), SAR11 might be responsible for an important portion of the assimilation observed within the LNA bacterial group. LNA bacteria at Stn ALOHA are responsible for an average of $42 \%$ of the total assimilation of dMet within the SML. This observation agrees with the expectation of LNA bacteria being responsible for an important fraction of the uptake of small dissolved organic molecules (Mary et al. 2006). Similar to our results, the contribution of LNA bacteria to dMet assimilation in a transect along the Atlantic was the same as expected based on its abundance (both 36\%; Mary et al. 2006). In the NPSG, LNA bacteria may outcompete other prokaryotes for labile compounds, not because of their percell assimilation rate but mainly as a result of their high abundance in these waters.

From our study, if we assume that all LNA bacterial cells are SAR11, then SAR11 assimilation of dDMSP would account for 38-63\% of total bacterial assimilation. However, a more realistic assumption would be to consider that $\sim 60 \%$ of LNA bacteria belong to the SAR11 clade (Mary et al. 2006, Schattenhofer et al. 2011), decreasing the SAR11 contribution to dDMSP assimilation to $23-38 \%$. This estimate agrees well with results from the Atlantic Ocean obtained using quantitative microautoradiography and fluorescence in situ hybridization that reported SAR11 being responsible for $30 \%$ of dDMSP assimilation in surface waters (Malmstrom et al. 2004a). The importance of SAR11 in the cycling of DMSP is highlighted in the fact that this group contributes $80 \%$ of the total gene pool for the key-degrading enzyme, DMSP demethylase $(d m d A)$, in the NPSG (Varaljay et al. 2012).

HNA bacteria are usually considered the more dynamic constituent of the bacterial assembly (Gasol et al. 1999, Lebaron et al. 2001, Longnecker et al. 2006), and this is in agreement with our observation of high per-cell assimilation rates of both dMet and dDMSP in surface waters. The highest per-cell assimilation rate of HNA bacteria, compared to PRO and LNA bacteria, may be due to their faster growth rate or may be only due to their larger size, since within the HNA bacterial group a positive relation between leucine incorporation and nucleic acid cell content and biovolume has been previously reported (Lebaron et al. 2002). 
All the sorted groups (i.e. PRO, LNA, and HNA) presented higher dMet assimilation during the night, which is in agreement with the finding of an overabundance of transcripts related to amino acid transport and metabolism during the night at Stn ALOHA for PRO and heterotrophic taxa (Poretsky et al. 2009). Our results are also in agreement with Mary et al. (2008), who reported a diel cycle for dMet assimilation by PRO in surface waters of the tropical Atlantic Ocean and in culture, with maximum assimilation at dusk and minimum assimilation at noon. At Stn ALOHA, assimilation of dDMSP into proteins also presented a clear diel cycle by all groups. Whether these patterns are imposed by metabolic regulation or are the result of a response to cross-species synchronous patterns is not known (Ottesen et al. 2013). The slower assimilation rate of dDMSP during the day may also be partially explained by the light history of the collected sample because negative effects of solar radiation, especially UV, on bacterial DMSP metabolism have been reported (Slezak et al. 2001, Ruiz-González et al. 2012).

\section{CONCLUSIONS}

The widespread capability of marine microbes to assimilate DMSP and amino acids (Cottrell \& Kirchman 2003, Malmstrom et al. 2004a,b, Vila et al. 2004) highlights the importance of these compounds to microbial metabolism. This study shows that dMet constitutes a very dynamic pool and a significant source of $\mathrm{S}$ to the microbial community at Stn ALOHA. However, during summer, dDMSP is the dominant $\mathrm{S}$ source, probably due to its higher concentration and availability.

Acknowledgements. We thank Chief Scientist S. Wilson for facilitating our research objectives. We also acknowledge K. Doggett for carrying out the flow cytometric sorting of the samples, as well as C. Suffridge and L. Cutter for their measurement of dMet concentrations. Finally, we thank 2 anonymous reviewers for helpful comments and suggestions. This research was supported by National Science Foundation (NSF) Grants EF-0424599 (D.M.K.), OCE-0928968 (R.P.K.), and OCE-0962209 (S.A.S-W.) as well as the Gordon and Betty Moore Foundation Marine Microbiology Investigator awards \#480.01 and \#3794 (D.M.K.).

\section{LITERATURE CITED}

Azam F, Hodson RE (1981) Multiphasic kinetics for D-glucose uptake by assemblages of natural marine bacteria. Mar Ecol Prog Ser 6:213-222
Carlucci AF, Craven DB, Henrichs SM (1984) Diel production and microheterotrophic utilization of dissolved free amino acids in waters off Southern California. Appl Environ Microbiol 48:165-170

$>$ Coffin RB (1989) Bacterial uptake of dissolved free and combined amino acids in estuarine waters. Limnol Oceanogr 34:531-542

Cottrell MT, Kirchman DL (2003) Contribution of major bacterial groups to bacterial biomass production (thymidine and leucine incorporation) in the Delaware estuary. Limnol Oceanogr 48:168-178

Degens ET (1970) Molecular nature of nitrogenous compounds in sea water and recent marine sediments. In: Hood DW (ed) Organic matter in natural waters. Inst Mar Sci Occas Publ 1. University of Alaska, Fairbanks, AK, p 77-106

del Valle DA, Kiene RP, Karl DM (2012) Effect of visible light on dimethylsulfoniopropionate assimilation and conversion to dimethylsulfide in the North Pacific Subtropical Gyre. Aquat Microb Ecol 66:47-62

Dupont CL, Rusch DB, Yooseph S, Lombardo MJ and others (2012) Genomic insights to SAR86, an abundant and uncultivated marine bacterial lineage. ISME $\mathrm{J}$ 6: 1186-1199

> Eiler A, Hayakawa DH, Church MJ, Karl DM, Rappé MS (2009) Dynamics of the SAR11 bacterioplankton lineage in relation to environmental conditions in the oligotrophic North Pacific subtropical gyre. Environ Microbiol 11:2291-2300

> Fuhrman JA, Ferguson RL (1986) Nanomolar concentrations and rapid turnover of dissolved free amino acids in seawater: agreement between chemical and microbiological measurements. Mar Ecol Prog Ser 33:237-242

Gage DA, Rhodes D, Nolte KD, Hicks WA, Leustek T, Cooper AJ, Hanson AD (1997) A new route for the synthesis of dimethylsulfoniopropionate in marine algae. Nature 387:891-894

> García-Fernández JM, de Marsac NT, Diez J (2004) Streamlined regulation and gene loss as adaptive mechanisms in Prochlorococcus for optimized nitrogen utilization in oligotrophic environments. Microbiol Mol Biol Rev 68: 630-638

Gasol JM, Zweifel UL, Peters F, Fuhrman JA, Hagström Å (1999) Significance of size and nucleic acid content heterogeneity as measured by flow cytometry in natural planktonic bacteria. Appl Environ Microbiol 65: 4475-4483

Gröne T, Kirst GO (1992) The effect of nitrogen deficiency, methionine and inhibitors of methionine metabolism on the DMSP contents of Tetraselmis subcordiformis (Stein). Mar Biol 112:497-503

- Hammer K, Brockmann U (1983) Rhythmic release of dissolved free amino acids from partly synchronized Thalassiosira rotula under nearly natural conditions. Mar Biol 74:305-312

Hill PG (2010) Bacterioplankton dynamics in surface waters of the north-eastern (sub-)tropical Atlantic Ocean affected by aeolian dust. PhD dissertation, University of Southampton, Southampton

Hill PG, Mary I, Purdie DA, Zubkov MV (2011) Similarity in microbial amino acid uptake in surface waters of the North and South Atlantic (sub-)tropical gyres. Prog Oceanogr 91:437-446

Hill PG, Warwick PE, Zubkov MV (2013) Low microbial respiration of leucine at ambient oceanic concentration in 
the mixed layer of the central Atlantic Ocean. Limnol Oceanogr 58:1597-1604

> Howard EC, Sun S, Reisch CR, del Valle DA, Bürgmann H, Kiene RP, Moran MA (2011) Changes in dimethylsulfoniopropionate demethylase gene assemblages in response to an induced phytoplankton bloom. Appl Environ Microbiol 77:524-531

- Iverson V, Morris RM, Frazar CD, Berthiaume CT, Morales RL, Armbrust EV (2012) Untangling genomes from metagenomes: revealing an uncultured class of marine euryarchaeota. Science 335:587-590

Karl DM, Lukas R (1996) The Hawaii Ocean Time-series (HOT) program: background, rationale and field implementation. Deep-Sea Res II 43:129-156

Keil RG, Kirchman DL (1991) Contribution of dissolved free amino acids and ammonium to the nitrogen requirements of heterotrophic bacterioplankton. Mar Ecol Prog Ser 73:1-10

Keller MD, Bellows W, Guillard R (1989) Dimethyl sulfide production in marine phytoplankton In: Saltzman E, Cooper WJ (eds) Biogenic sulfur in the environment. American Chemical Society, New York, NY, p 167-182

- Kiene RP, Linn LJ (2000) The fate of dissolved dimethylsulfoniopropionate (DMSP) in seawater: tracer studies using ${ }^{35}$ S-DMSP. Geochim Cosmochim Acta 64:2797-2810

Kiene RP, Service SK (1991) Decomposition of dissolved DMSP and DMS in estuarine waters: dependence on temperature and substrate concentration. Mar Ecol Prog Ser 76:1-11

Kiene RP, Slezak D (2006) Low dissolved DMSP concentrations in seawater revealed by small volume gravity filtration and dialysis sampling. Limnol Oceanogr Methods 4: 80-95

Kiene RP, Linn LJ, González J, Moran MA, Bruton JA (1999) Dimethylsulfoniopropionate and methanethiol are important precursors of methionine and protein-sulfur in marine bacterioplankton. Appl Environ Microbiol 65: 4549-4558

Kiene RP, Linn LJ, Bruton JA (2000) New and important roles for DMSP in marine microbial communities. J Sea Res 43:209-224

Kirchman D, K'nees E, Hodson R (1985) Leucine incorporation and its potential as a measure of protein synthesis by bacteria in natural aquatic systems. Appl Environ Microbiol 49:599-607

> Kujawinski EB (2011) The impact of microbial metabolism on marine dissolved organic matter. Annu Rev Mar Sci 3: 567-599

Lebaron P, Servais P, Agogue H, Courties C, Joux F (2001) Does the high nucleic acid content of individual bacterial cells allow us to discriminate between active cells and inactive cells in aquatic systems? Appl Environ Microbiol 67:1775-1782

Lebaron P, Servais P, Baudoux AC, Bourrain M, Courties C, Parthuisot N (2002) Variations of bacterial-specific activity with cell size and nucleic acid content assessed by flow cytometry. Aquat Microb Ecol 28:131-140

> Li WKW, Jellett JF, Dickie PM (1995) DNA distributions in planktonic bacterial stained with TOTO or TO-PRO. Limnol Oceanogr 40:1485-1495

> Longnecker K, Sherr BF, Sherr EB (2006) Variation in cellspecific rates of leucine and thymidine incorporation by marine bacteria with high and with low nucleic acid content off the Oregon coast. Aquat Microb Ecol 43:113-125 > Luo S, Levine RL (2009) Methionine in proteins defends against oxidative stress. FASEB J 23:464-472

> Malmstrom RR, Kiene RP, Cottrell MT, Kirchman DL (2004a) Contribution of SAR11 bacteria to dissolved dimethylsulfoniopropionate and amino acid uptake in the North Atlantic Ocean. Appl Environ Microbiol 70:4129-4135

Malmstrom RR, Kiene RP, Kirchman DL (2004b) Identification and enumeration of bacteria assimilating dimethylsulfoniopropionate (DMSP) in the North Atlantic and Gulf of Mexico. Limnol Oceanogr 49:597-606

- Martínez-García S, Fernández E, del Valle DA, Karl DM, Teira E (2013) Experimental assessment of marine bacterial respiration. Aquat Microb Ecol 70:189-205

> Mary I, Heywood JL, Fuchs BM, Amann R, Tarran GA, Burkill PH, Zubkov MV (2006) SAR11 dominance among metabolically active low nucleic acid bacterioplankton in surface waters along an Atlantic meridional transect. Aquat Microb Ecol 45:107-113

> Mary I, Tarran GA, Warwick PE, Terry MJ, Scanlan DJ, Burkill PH, Zubkov MV (2008) Light enhanced amino acid uptake by dominant bacterioplankton groups in surface waters of the Atlantic Ocean. FEMS Microbiol Ecol 63:36-45

> Michelou VK, Cottrell MT, Kirchman DL (2007) Light-stimulated bacterial production and amino acid assimilation by cyanobacteria and other microbes in the North Atlantic Ocean. Appl Environ Microbiol 73:5539-5546

> Miller TR, Hnilicka K, Dziedzic A, Desplats P, Belas R (2004) Chemotaxis of Silicibacter sp. strain TM1040 toward dinoflagellate products. Appl Environ Microbiol 70: 4692-4701

Ottesen EA, Young CR, Eppley JM, Ryan JP, Chavez FP, Scholin CA, DeLong EF (2013) Pattern and synchrony of gene expression among sympatric marine microbial populations. Proc Natl Acad Sci USA 110:E488-E497

Poretsky RS, Hewson I, Sun S, Allen AE, Zehr JP, Moran MA (2009) Comparative day/night metatranscriptomic analysis of microbial communities in the North Pacific subtropical gyre. Environ Microbiol 11:1358-1375

Reisch CR, Moran MA, Whitman WB (2011) Bacterial catabolism of dimethylsulfoniopropionate (DMSP). Front Microbiol 2:172

Riley GA (1971) Particulate organic matter in sea water. Adv Mar Biol 8:1-118

Rocap G, Larimer F, Lamerdin J, Malfatti S and others (2003) Genome divergence in two Prochlorococcus ecotypes reflects oceanic niche differentiation. Nature 424: 1042-1047

> Ruiz-González C, Galí M, Gasol JM, Simó R (2012) Sunlight effects on the DMSP-sulfur and leucine assimilation activities of polar heterotrophic bacterioplankton. Biogeochemistry 110:57-74

Sañudo-Wilhelmy SA, Cutter LS, Durazo R, Smail EA and others (2012) Multiple B-vitamin depletion in large areas of the coastal ocean. Proc Natl Acad Sci USA 109: 14041-14045

> Schattenhofer M, Wulf J, Kostadinov I, Glöckner FO, Zubkov MV, Fuchs BM (2011) Phylogenetic characterisation of picoplanktonic populations with high and low nucleic acid content in the North Atlantic Ocean. Syst Appl Microbiol 34:470-475

> Seymour JR, Simó R, Ahmed T, Stocker R (2010) Chemoattraction to dimethylsulfoniopropionate throughout the marine microbial food web. Science 329:342-345

Sievert SM, Kiene RK, Schulz-Vogt HN (2007) The sulfur cycle. Oceanography 20:117-123 
Slezak D, Brugger A, Herndl GJ (2001) Impact of solar radiation on the biological removal of dimethylsulfoniopropionate and dimethylsulfide in marine surface waters. Aquat Microb Ecol 25:87-97

Stefels J (2000) Physiological aspects of the production and conversion of DMSP in marine algae and higher plants. J Sea Res 43:183-197

Stefels J (2007) Sulfur in the marine environment. In: Hawkesford MJ, De Kok LJ (eds) Sulfur in plants: an ecological perspective. Springer, Dordrecht, p 77-90

Stefels J, Gieskes WWC, Dijkhuizen L (1996) Intriguing functionality of the production and conversion of DMSP in Phaeocystis sp. In: Kiene RP, Visscher PT, Keller MD, Kirst GO (eds) Biological and environmental chemistry of DMSP and related sulfonium compounds. Plenum Press, New York, NY, p 307-313

Sunda W, Kieber DJ, Kiene RP, Huntsman S (2002) An antioxidant function for DMSP and DMS in marine algae. Nature 418:317-320

Suttle C, Chan A, Fuhrman J (1991) Dissolved free amino acids in the Sargasso Sea: uptake and respiration rates, turnover times, and concentrations. Mar Ecol Prog Ser 70:189-199

Tripp HJ, Kitner JB, Schwalbach MS, Dacey JW, Wilhelm LJ, Giovannoni SJ (2008) SAR11 marine bacteria require exogenous reduced sulphur for growth. Nature 452: 741-744

- Varaljay VA, Gifford SM, Wilson ST, Sharma S, Karl DM, Moran MA (2012) Bacterial dimethylsulfoniopropionate degradation genes in the oligotrophic North Pacific Subtropical Gyre. Appl Environ Microbiol 78:2775-2782

Vila M, Simó R, Kiene RP, Pinhassi J, González JM, Moran MA, Pedrós-Alió C (2004) Use of microautoradiography

Editorial responsibility: Josep Gasol,

Barcelona, Spain combined with fluorescence in situ hybridization to determine dimethylsulfoniopropionate incorporation by marine bacterioplankton taxa. Appl Environ Microbiol 70:4648-4657

Vila-Costa M, Gasol JM, Sharma S, Moran MA (2012) Community analysis of high and low nucleic acid containing bacteria in NW Mediterranean coastal waters using 16S rDNA pyrosequencing. Environ Microbiol 14: 1390-1402

> Welsh DT (2000) Ecological significance of compatible solute accumulation by micro-organisms: from single cells to global climate. FEMS Microbiol Rev 24:263-290

Wright RR, Hobbie JE (1966) Use of glucose and acetate by bacteria and algae in aquatic ecosystems. Ecology 47 : 447-464

Zubkov MV, Tarran GA (2005) Amino acid uptake of Prochlorococcus spp. in surface waters across the South Atlantic Subtropical Front. Aquat Microb Ecol 40: 241-249

Zubkov MV, Fuchs BM, Archer SD, Kiene RP, Amann R, Burkill PH (2001) Linking the composition of bacterioplankton to rapid turnover of dissolved dimethylsulphoniopropionate in an algal bloom in the North Sea. Environ Microbiol 3:304-311

Zubkov MV, Fuchs BM, Tarran GA, Burkill PH, Amann R (2003) High rate of uptake of organic nitrogen compounds by Prochlorococcus cyanobacteria as a key to their dominance in oligotrophic oceanic waters. Appl Environ Microbiol 69:1299-1304

Zubkov MV, Tarran GA, Fuchs BM (2004) Depth related amino acid uptake by Prochlorococcus cyanobacteria in the Southern Atlantic tropical gyre. FEMS Microbiol Ecol 50:153-161

Submitted: October 9, 2014; Accepted: March 10, 2015 Proofs received from author(s): May 2, 2015 